\title{
BERTOLT BRECHT E AS IDEOLOGIAS DE TEMPOS SOMBRIOS
}

\author{
Günther Richter Mros*
}

\section{Resumo}

Este artigo, excerto de monografia apresentada como conclusão do curso de Relações Internacionais, busca a compreensão de alguns fatos atinentes à realidade alemã no período da Segunda Guerra Mundial. Esta leitura se dá através de uma obra de teatro, escrita por Bertolt Brecht - poeta alemão com forte pensamento marxista -, e através do uso de conceitos amplamente trabalhados no campo da Ciência Política. As análises de Antonio Gramsci, em seus Quaderni Del Cárcere, sobre parte do cenário político que envolve a primeira metade do século XX, estão presentes aqui como fonte para interpretação do texto de Brecht.

Palavras-chave: Política. Totalitarismo. Nazismo. Segunda Guerra Mundial. Teatro. Cultura.

\begin{abstract}
The main article is a result of the essay written as the conclusion of the International Relations degree. The reading of a dramatic text by Bertolt Brecht-Marxist German poet - in which he applies widely discussed concepts in the field of political science views, try to explain some important political facts which are pertinents to the Germans reality during the second world war. The analysis of Gramsci's "Quaderni del Carcere" is applied to this reading of Brecht's work.
\end{abstract}

Key-words: Politics. Totalitarism. Nazism. Second World War. Theater. Culture.

\section{Introdução}

O artigo que se apresenta a seguir é um excerto da monografia de final de curso produzida como requisito para o grau de bacharel em Relações Internacionais do UniCEUB. Temas atinentes ao campo científico das Relações Internacionais - tais como: ideologia; totalitarismo; guerra; hegemonia. - puderam ser trabalhados tendo uma peça de teatro como fonte primária da idéia que se pode tirar a respeito da Alemanha Nazista.

Antonio Gramsci serve, com suas análises contidas nos Quaderni Del Carcere, como leitura de diversos conceitos evidenciados na obra de Brecht, especialmente sua definição de intelectual orgânico, à qual Bertolt Brecht, dramaturgo e poeta alemão, pode ser enquadrado.

Não menos importante deve ser a observância de que Brecht foi ator, como homem e teatrólogo, das relações internacionais com letras minúsculas, que se referem ao transcorrer histórico de um cenário específico do século XX. Este é, portanto, também um esforço dialético que envolve a teoria e a práxis; a ciência e a história.

\footnotetext{
* Ator e Bacharel em Relações Internacionais pelo Centro Universitário de Brasília - UniCEUB.
} 
Terror e Miséria do Terceiro Reich é um panorama da vida na Alemanha nazista, foi escrita entre 1935 e 1938, fazendo uso de recortes de jornal, notícias recebidas da resistência - Brecht vivia então na Dinamarca -, rádio, ou qualquer forma que pudesse levar a informação além das fronteiras do Reich. "(...) é um veemente documento: analisa opressores e oprimidos, assim como a penetração do terror e do medo no cotidiano das famílias alemãs (...)". ${ }^{1}$ Composta de vinte e quatro cenas que não têm uma seqüência apresenta diversas situações cotidianas, com juízes, policiais, professores dentre outros. $\mathrm{O}$ Führer é um personagem de fundo, sempre citado, mas nunca aparecendo de fato.

Algumas cenas serão destacadas por estarem contidos nelas os conceitos de totalitarismo, liberdades individuais e invasão da esfera privada por parte do Estado.

Em seguida, faremos uma leitura das características pessoais de Brecht como intelectual orgânico, contraditório em sua essência, e único em sua complexidade. Dentro dessa leitura uma pequena imersão na situação dos intelectuais da atualidade e sua influência nas discussões que envolvem as Relações Internacionais. A intenção aqui está longe de buscar um esgotamento do assunto, mas muito antes fazer um quadro comparativo entre a atuação dos intelectuais de os chamados "tempos sombrios" com os homens que se propõem a defender os valores de nossos dias. Os desafios e metas de ambos e as possibilidades que os intelectuais desse início de século XXI têm de poder realizar algo de relevante.

A discussão que se fará sobre esses intelectuais se dará através de algumas de suas obras, sempre levando em conta, no entanto, que a obra deles em si não é o tema do debate, mas um mote para classificá-los como intelectuais orgânicos ou não.

Talvez o debate fosse o grande objetivo de Bertolt Brecht quando escreveu Terror e Miséria nos anos trinta. Talvez fosse sua intenção provocar mais indagações do que certezas, e se uma certeza houvesse, esta seria de que os tempos em que vivera eram de fato tempos sombrios.

\section{Terror e Miséria, a Alemanha nazista sob a luneta de um observador}

Dentre tantas palavras que precisam ser ditas a respeito de Terror e Miséria do Terceiro Reich talvez uma das mais importantes é que esta peça não se enquadra no perfil consagrado da obra brechtiana. Como bem destaca Martin Esslin, são esquetes “... escritas num estilo bem pouco brechtiano, de convenção naturalista"2. Engloba aspectos poéticos de sua obra, mas também, e principalmente, os aspectos panfletários de sua visão política.

Pela primeira vez Brecht e o terceiro Reich estão frente à frente. O título sugestivo da adaptação feita por Eric Bentley em montagem realizada em Nova Iorque, The Private Life of Master Race, traz uma noção talvez mesmo até mais esclarecedora sobre o conteúdo da peça. São os aspectos da vida privada, cujo cerne é a família, que são os mais usurpados pelo Estado totalitário alemão. Em cada cena, fica a sensação de uma condenação sem nenhum tipo de lógica ou justiça.

Terror e Miséria tem em cada cena a precedência de um pequeno verso sobre o que será discutido, alguns desses versos com bastante força sarcástica, essa sim uma marca identificável em toda a obra de Brecht.

\footnotetext{
${ }^{1}$ PEIXOTO, Fernando. Brecht, vida e obra. Rio de Janeiro: Paz e Terra, 1991, p. 168.

${ }^{2}$ ESSLIN, Martin. Brecht: dos males o menor, um estudo crítico do homem, suas obras e suas opiniões. Rio de Janeiro: Zahar Editores, 1979, p.302.
} 
A seguir, três destas cenas que aparecem destacadas pela crítica - inclusive nos livros de Esslin e Fernando Peixoto - tanto do ponto de vista da sua força artística quanto do seu teor político. Há, no entanto, que se fazer um pequeno destaque ao poema que aparece abrindo a obra, A Grande Parada Militar Alemã:

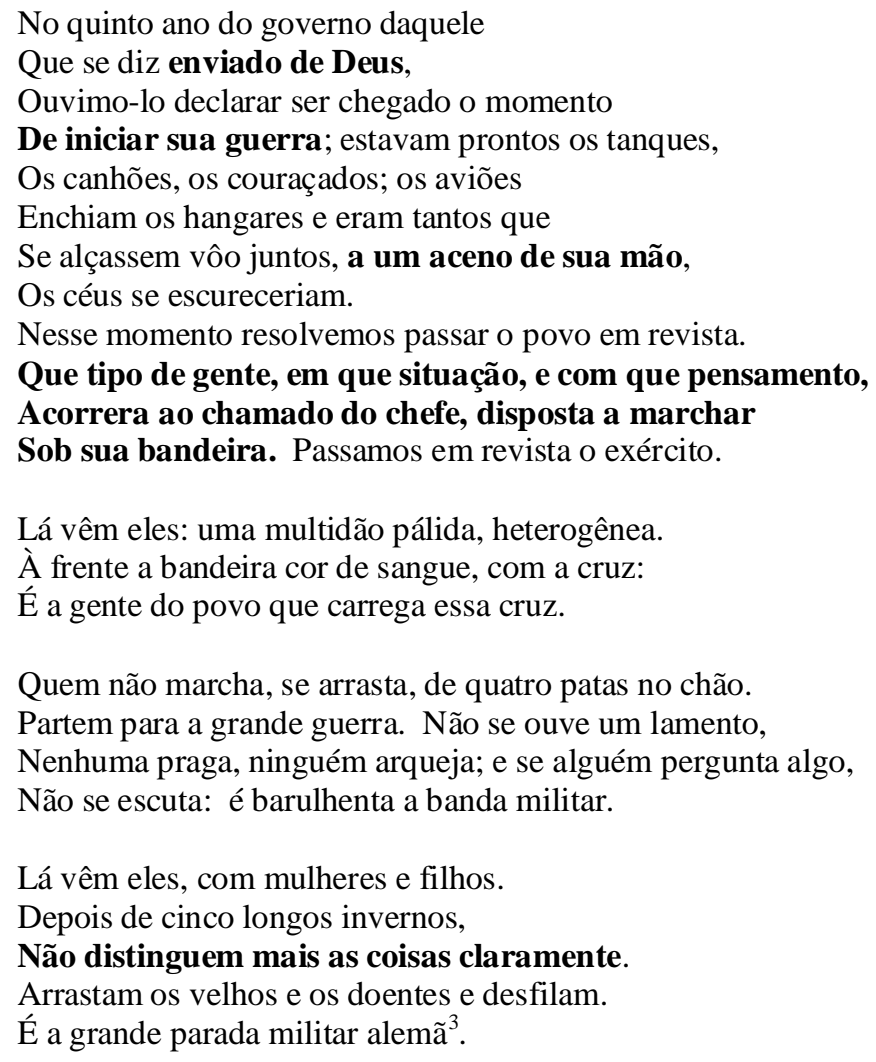

É possível se fazer aqui o reconhecimento de alguns pontos-chave para a leitura da obra. As palavras em negrito representam a força de uma opinião, uma análise política. Brecht quando se refere a Hitler como aquele que se diz "enviado de Deus" pode estar fazendo a leitura de algo mais do que uma hipocrisia, ou um carisma. Brecht chama a atenção para o discurso messiânico que existe no Führer nazista. É um discurso inflamado, que assume uma postura paternalista perante o povo alemão, principalmente entre os mais pobres, que sofrem com uma política econômica weimariana, favorecedora de especuladores de uma burguesia ascendente.

A guerra é de Hitler, mesmo que esta tenha sido aprovada e desejada pela aristocracia militar prussiana, ela é iniciada "a um aceno de sua mão". Aceno este que foi construído junto com o Partido Nacional-Socialista, mas que vinha sendo ensaiado desde o dia em que o próprio Hitler presenciou a assinatura do Tratado de Versalhes. Já nos esboços iniciais do partido nazista, a intenção de sua política externa era a guerra.

Uma das indagações mais freqüentes ao longo desta peça reside na tentativa de entender quem são de fato aquelas pessoas que, como por encantamento, viram-se inebriadas em um estado de torpor frente ao nacional-socialismo. Brecht está intrigado

\footnotetext{
${ }^{3}$ BRECHT, Bertolt. Coleção Teatro. Direção de Fernando Peixoto. Rio de Janeiro: Paz e Terra, 1991 , vol. 12, p. 183 (grifo meu).
} 
com aquela passividade mesmo que esta tenha explicações históricas, isto porque os fatos não incluem a moral de um pensamento cristão-protestante. "Que tipo de gente, em que situação e com que pensamento, acorrera ao chamado do chefe...", pode ser que haja explicações, mas onde estava a moral, o senso crítico daquelas pessoas? Talvez chamuscado ou aniquilado por toda uma máquina de opressão chamada Estado. O limite entre a opressão e a capacidade de reação é realmente algo que não poderia transparecer em meias palavras.

No entanto, é provável que não haja nesse poema a intenção de inflamar, mas de refletir sobre aquela visão estarrecedora. Se "não distinguem mais as coisas claramente", não pode haver senso crítico, nem moral. E tudo o que resta pode vir a ser poesia, uma poesia maldita.

\section{A cruz de giz}

\footnotetext{
"Como matilha de cães de caça, os SA farejam seus semelhantes e os perseguem. Atiram a presa aos pés dos gordos magnatas e fazem a saudação com o braço em riste. Têm a s mãos vazias e sangrentas."
}

A cruz de giz é uma cena emblemática desta peça: é quase tão citada quanto a própria obra em que ela está inserida. Passa-se na Berlim de 1933, em uma cozinha de uma grande casa de uma família rica e tem como personagens um SA que vem visitar sua namorada, empregada na tal casa e se gaba das qualidades da instituição da qual ele faz parte. Além dos dois, aparecem uma cozinheira, um motorista e o irmão da cozinheira, um operário desempregado.

O conflito da cena está no discurso do SA com o operário, que hesita em dar palpites que possam deflagrá-lo como suspeito.

Desde o início da cena, Theo, o SA, se gaba de não lhe escapar nada aos olhos e ouvidos atentos. Ele questiona, no entanto, se a família dona da casa não pode entrar a qualquer momento. O totalitarismo na Alemanha não foi um regime que desrespeitasse a burguesia, muito pelo contrário, teve nesta uma aliada para a sua ascensão.

Num segundo momento, junto da entrada de um operário em cena a empregada traz um pouco de cerveja para Theo que exibe uma brincadeira de caserna ao bebê-la sem que ninguém tenha visto e então acusar a falta da mesma. O operário entra na piada e bebe um segundo copo para depois com um ar de deboche dizer que é fácil sumir com a cerveja. Neste momento o SA, após a ida do operário com sua irmã aos fundos, questiona o motorista se aquele sujeito seria de fato cem por cento fiel ao partido. No regime nazista, o partido se confundia com o Estado, e uma traição a qualquer um dos dois era dos piores crimes. Theo afirma então que "jamais suspeita de coisa alguma. Suspeita, o senhor compreende, é quase a mesma coisa que certeza"

Em Origens do Totalitarismo Hannah Arendt trabalha esse aspecto em que a verdade não é mais algo que possa ser diferenciado ${ }^{6}$. O bom senso não é mais um fator real, mas algo totalmente manipulado por Leis da Natureza baseadas na eugenia. Perde-se a noção do que seja de fato correto ou incorreto. Num Estado totalitário o indivíduo é

\footnotetext{
${ }^{4}$ Ibidem, p. 186.

${ }^{5}$ Ibidem, p. 190.

${ }^{6}$ ARENDT, Hannah. Origens do Totalitarismo. São Paulo: Companhia das Letras, 1989, p. 515.
} 
isolado de todo e qualquer aparelho público ou privado em que pudesse exprimir suas vontades, anseios ou críticas. Esse isolamento que Arendt diferencia da solidão onde o indivíduo está em meio aos seus semelhantes, mas com o sentimento de estar só, é exacerbado propositalmente pelo Estado. É a base do terror. Os nazistas criaram uma atmosfera lúdica de que haveria uma conspiração universal contra o povo alemão. $O$ fato de Theo, o SA, dizer que suspeita não há - se houvesse seria certeza - é o expurgo de qualquer tentativa em se criar um questionamento por mais simples que seja. Se voltarmos em Locke e sua assertiva de que o bom senso do indivíduo juntamente com seus direitos morais e sua propriedade privada protegidos seria o suficiente para a harmonia de uma sociedade, teremos então o Estado totalitário como o oposto explícito do liberalismo. Isso já foi afirmado por Hayek - ao diferenciar o liberalismo original daquele mais voltado para a representatividade -, mas essa constatação chama a atenção para um fato levantado por Hobsbawm: uma "união bizarra"7 de socialistas e liberais contra o inimigo comum nazista.

Um ponto de congruência entre liberais e socialistas reside no núcleo moral, isto é, enquanto as divergências políticas e principalmente econômicas servem de mote para uma Guerra Fria os direitos morais têm para essas duas escolas, evidentemente em se falando de uma visão ocidental, uma forte inspiração nos preceitos cristãos. Quando Brecht, um marxista, se dispõe a defender direitos individuais não significa que ele tenha se tornado mais liberal ou menos socialista, mas que os direitos morais, aqueles que buscam preservar a humanidade de uma maneira geral são o que há de mais prejudicado na concepção nazista de mundo. Com a política de expansão desse regime, mais cedo ou mais tarde tanto liberais quanto socialistas serão afetados como seres humanos.

$\mathrm{O}$ truque da cerveja serve nesta cena para que o SA possa demonstrar como usa uma de suas técnicas de identificação de inimigos do Reich, o truque da cruz de giz. Theo lembra que ninguém chega dizendo nada para ele, mas que as informações estão sempre ali, próximas e que ele vai buscá-las. Aqui, os inimigos do Reich são operários desempregados na fila dos pontos de carimbo.

Todas as manhãs os SA estão infiltrados nas filas, para ouvir os murmúrios daqueles que estão insatisfeitos com o Reich. Mas quando o operário afirma que depois da primeira delação Theo ficaria manjado (é esta a palavra usada por Brecht), este começa a explicar como faz para escutar sem ser notado: "quando os caras percebem que não podem escapar, que nós sabemos de tudo, acabam desistindo...". onipresença do Estado nazista. E Brecht coloca na boca da cozinheira a perseguição que ele mesmo sofre com este Estado onipresente: "Todos os marxistas devem ser desmascarados. Não se pode tolerar que eles acabem com tudo"9.

Ao seguir a conversa com o objetivo de mostrar qual o truque para se ouvir tudo e todos, Theo usa o exemplo da eterna queixa dos desempregados quanto ao serviço voluntário, e explica como este serviço deve ser feito.

O operário, no entanto, com a história da visita de um alto funcionário da antiga República de Weimar a um campo de trabalho ${ }^{10}$ dá a sua versão: o funcionário questionou

\footnotetext{
${ }^{7}$ HOBSBAWM, Eric. Era dos extremos: o breve século XX: 1914-1991. São Paulo: Companhia das Letras, 2003 , p. 17.

${ }^{8}$ BRECHT, Bertolt. Op. cit, p. 193.

${ }^{9}$ Ibidem, p. 194.

${ }^{10}$ Brecht aqui diferencia esses campos de trabalho dos campos de concentração. O primeiro, voltado para o serviço voluntário, recebia a visita da organização Força e Alegria, uma organização que servia de nada e acumulava ex-funcionários de alto escalão de Weimar.
} 
um comandante como eles conseguiram que trabalhadores que antes tanto reclamavam agora aceitem qualquer coisa. Ao que o comandante respondeu com uma piadinha: a de como fazer um gato comer mostarda voluntariamente; aplicasse a mostarda no ânus do mesmo para que ele em agonia se lambesse rapidamente. "Agora, diz triunfante o Dr. Ley, o gato está comendo! Assim é o trabalho voluntário!"11.

Nesta cena existem diversos recursos de Brecht para falar dos aspectos mais expressivos do Reich, como ainda sobre as delações, quando o operário simula uma discussão sua com uma transeunte - evidentemente tentando se desfazer do rótulo de suspeito - em que diz que "até minha própria mãe, se começar a se queixar do preço da margarina, eu entrego...."12.

Depois desse discurso, após um tapinha nas costas e da promessa de Theo de que jamais o delataria, o operário sairia da fila e seria imediatamente preso. Por quê? Para espanto de todos Theo manda que o operário se vire e mostre suas costas, onde se encontra uma cruz branca, feita com giz na altura do ombro.

Pouco depois o fim da cena se encaminha com uma discussão sobre o dinheiro na poupança dos namorados, o SA e a empregada, e após a saída do mesmo de cena ela chora e afirma para a amiga que Theo não é mais o mesmo. Ela tem até medo de estar com uma cruz desenhada nas costas.

Esta cena é uma das maiores da peça e gira muito em torno da delação e como em toda a obra, Brecht também trabalha a intromissão do Estado na vida privada, até mesmo, numa relação amorosa.

Um outro aspecto do totalitarismo é o de ter sob a esfera de seu controle todos os poderes que fazem parte do Estado, e com o poder judiciário não é diferente. Há, no entanto, uma característica do regime nazista que se diferencia do totalitarismo soviético. Enquanto o regime de Stalin se baseia na história, o de Hitler busca uma legitimação científica de suas funções perante o povo alemão através da Teoria da Evolução das Espécies, de Darwin. Sendo assim, o justo na Alemanha nazista vem a ser um conceito abstrato, e os juízes se tornam fantoches de uma política racista.

Brecht trabalha essa situação em uma cena de Terror e Miséria do Terceiro Reich com a exposição de um sistema judiciário que beira ao ridículo; risível se não fosse espelho de uma situação verossímil.

\section{Em busca da justiça}

\footnotetext{
“Aqui estão os senhores juízes. Os canalhas lhes disseram: justo é tudo o que melhor serve ao povo alemão. Eles responderam: e como saber ao certo? Agora eles têm de julgar a todos, até que o povo inteiro esteja na prisão" ${ }^{13}$.
}

Esta cena se passa na pequena Augsburg, terra natal de Brecht, nos idos de 1934. Tem como principal conflito a dificuldade de um juiz em definir, e julgar, a ação de três SA que depredaram uma relojoaria e agrediram o seu dono, um judeu. A grande dificuldade está no fato de que o sócio não era judeu e tem bons contatos na SA.

Um dos aspectos que devem ser mencionados sobre a cena está no fato de que a mesma é bastante confusa, e talvez tenha sido esta a intenção de Brecht. Quando se toma

\footnotetext{
${ }^{11}$ Ibidem, p. 197.

${ }^{12}$ Ibidem, p. 198.

${ }^{13}$ Ibidem, p. 209.
} 
conhecimento de toda a história fica a sensação de estar perdido exatamente como o juiz que deve encontrar uma sentença para o caso. O autor conduz o leitor através dos olhos e ouvidos do juiz e, por isso mesmo, essa sensação de estar desorientado fica implícita. Será que era isso mesmo? Fica a indagação diante de tão ridícula situação para alguém que viva em meio a um regime onde exista uma normaticidade mínima de leis. Aqui, como na cena anterior volta à tona a questão do certo e errado e da falta de bom senso.

No princípio da cena o inspetor geral apresenta os fatos ao juiz: três SA, os senhores Häberle, Schünt e Gaunitzer agrediram o senhor Arndt e causaram prejuízos à joalheria que leva seu nome. A SA não viu motivos para fazer uma repreensão aos mesmos, que continuam suas atividades normalmente. Houve uma agressão na nuca do senhor Arndt, de 54 anos de idade e danos materiais. Essa é toda a informação contida nos autos, ao que o juiz se diz estarrecido com a péssima redação do relatório.

A partir desse momento começa o martírio do juiz, já que a ação parece não ter motivo esclarecido. Mas sumiram jóias! O conselho do inspetor é claro: "cá entre nós, quanto menos compreender melhor, ${ }^{\text {, }}$.

O juiz busca saber então se houve uma provocação por parte do velho judeu contra os SA. Segundo depoimento dos mesmos houvera essa provocação por parte de Arndt e de um desocupado, chamado Wagner que fora contratado para remover a neve da frente da loja. O sócio da loja, um ariano, diz ter ouvido as injúrias desferidas aos SA e o juiz não imagina como ele pode querer testemunhar contra o sócio, já que não receberá desta forma nenhuma indenização. Mas o inspetor lembra que a indenização não importa, o sócio ficaria com a loja como benefício pela má conduta de Arndt. Outro aspecto dessa cena que chama a atenção está inserido na discussão existente entre liberalismo e totalitarismo. O aspecto econômico do liberalismo não defende somente um mercado livre, mas também a necessidade de ascensão das classes médias sobre a velha estrutura fundiária. O oposto disso é o que ocorre na Alemanha nazista, onde a ação do partido se baseia em uma política econômica que tem exatamente o apoio e a cumplicidade dessa aristocracia fundiária. Os judeus representavam na República de Weimar aquela classe que vinha crescendo economicamente não só graças à especulação, mas também ao fazer uso do comércio.

Nesta etapa, no entanto, entra em cena o promotor com novas informações: segundo uma testemunha, o dono do prédio presenciou o fato e disse que os insultos partiram de Wagner, o desocupado, e que o senhor Arndt nem na cena estava. O dono do prédio, Von Miehl, faz parte dos quadros da SS - já fez um dia queixas contra Arndt - e vai testemunhar em favor do judeu. O juiz confuso diz: “... o próprio sócio que eu pensei que fosse defender o velho judeu, vai acusá-lo. E o proprietário da casa, que antes o havia denunciado, vai depor em seu favor. E ainda me diz que é tudo muito claro?"15.

O juiz pergunta por Arndt, que segundo o promotor está numa clínica e Wagner, que está num campo de concentração. O juiz aliviado chega à conclusão de que para a SA o que importa é definir que houve impropérios, “... não importa muito se partiu do judeu ou do marxista" $"$. Note-se aqui que o sujeito definido pelo relatório do inspetor como sendo um desocupado é na verdade um marxista. Os marxistas da Alemanha da República de Weimar estavam muito ligados ao movimento sindical e aos movimentos grevistas, tira-se daí talvez a depreciação do NSDAP (partido nazista) com os integrantes de uma corrente

\footnotetext{
${ }^{14}$ Ibidem, p. 212.

${ }^{15}$ Ibidem, p. 217.

${ }^{16}$ Ibidem, p. 217.
} 
proletária, que depois se transformou em perseguição com a proibição dos sindicatos. É preciso lembrar, no entanto, que Brecht é o autor, é marxista e deve ter recebido esta alcunha - a de desocupado - pessoalmente algumas vezes.

As perseguições na Alemanha nazista não se davam, como muitas vezes é passado em filmes somente aos judeus. Havia uma série de minorias que eram perseguidas de acordo com os conceitos de inferioridade. Os marxistas desde o fim da Primeira Guerra Mundial tinham uma forte presença na sociedade alemã. $O$ partido comunista era o segundo maior, logo atrás dos social-democratas. O KPD (partido comunista alemão) era perseguido pela direita com maior afinco principalmente após a revolução espartakista e o assassinato de Karl Liebknecht e Rosa Luxemburgo. O movimento dos comunistas se justificava em pessoas como Wagner, que na verdade é um operário desempregado. Gramsci já trabalhava em seus Quaderni com o fato de que a hegemonia deve ser buscada por um grupo através dos aparelhos privados de que dispõe a sociedade civil.

Segundo o conceito trabalhado por Marilena Chauí de sociedade civil, esta é composta de aristocracia, funcionários públicos e no seu núcleo por operários; poderíamos então, tirar da cena mais uma evidência. O foco de destruição do regime nazista é a sociedade civil, e nela o seu núcleo operário como sendo o mais perigoso. A aristocracia, principalmente a militar prussiana, está fechada com Hitler. Os funcionários públicos são escolhidos pelo próprio Estado. Essa é uma diferença das mais evidentes do regime nazista para o regime comunista de Stalin. Teoricamente o comunismo busca nos operários os agentes da revolução para que futuramente a sociedade política, isto é, os aparelhos de coerção do Estado, sejam eliminados. No nazismo, o Estado deve ser sempre fortificado.

O marxismo representa ao Estado nazista um mal que deve ser esmagado porque é a expressão do proletariado, tem nos trabalhadores o foco da tomada do poder. $\mathrm{O}$ totalitarismo não tolera questionamentos, e a alternativa tanto liberal quanto marxista é inaceitável. Mas o regime nazista tem em seu nome algo que poderia ser questionado como aproximação com o socialismo, afinal, é o Partido Nacional-Socialista. Eduardo Szklarz cita Marlis Steinert quando esta lembra que o socialismo dos nazistas era baseado na afirmação de que o coletivo supostamente deveria se sobrepor ao indivíduo através de ações do Estado. "Prosperidade coletiva" nas palavras de Marlis ${ }^{17}$.

Quanto ao ódio a judeus, homossexuais, deficientes, ciganos e todos aqueles que se diferenciavam do padrão ariano escolhido como o perfeito, era um ódio que fazia parte do imaginário europeu do início do século XX baseado nos conceitos de eugenia ${ }^{18}$.

Voltando à cena, o promotor insiste que o juiz deve se esmerar em buscar o justo, e o justo segundo definição do ministro da justiça “... é tudo o que concorra a beneficiar os

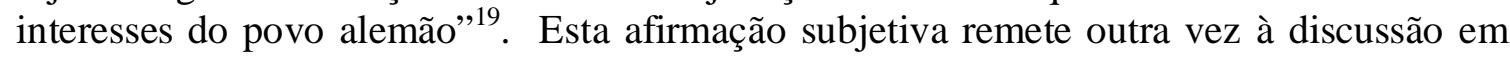
Arendt sobre o bom senso com o acréscimo de que aqui o juiz está na posição de isolado frente ao terror. Não importa o seu julgamento, ele deve satisfazer o regime, mas a certa altura não é possível nem mesmo saber o que satisfaz mais ao regime.

\footnotetext{
${ }^{17}$ STEINERT, Marlis. Hitler y el Universo Hitleriano. Argentina: Ediciones B., 2004, apud SZKLARZ, Eduardo. Revista Superinteressante, São Paulo, ano 19, nº 7, Edição 215, p. 42, Jul 2005.

${ }^{18}$ Recentemente uma jornalista do The New York Times ao visitar Pyongyang, capital norte-coreana - país que está sob características semelhantes àquelas vividas por regimes totalitários - ficou chocada em saber que deficientes e pessoas que o regime define como feias não podem viver na capital. Isto é, o fenômeno racista está presente. KRISTOF, Nicholas D. A Sucker Bet. The New York Times, Nova Iorque, 17 Jul 2005. Opinion.

${ }^{19}$ BRECHT, Bertolt. Op. cit., p. 218.
} 
Logo após a saída do promotor, o inspetor retorna dizendo que Wagner não poderia ter sido escutado por Von Miehl porque este foi ferido na Primeira Guerra no pescoço e não consegue falar em voz alta. O inspetor lembra o juiz de que o promotor pode estar de olho em seu cargo, e que se o mesmo inocentar o judeu qualquer pessoa simples do Reich poderia tirar conclusões negativas: um judeu pedindo indenização à SA? “(...) Pode fazer uma idéia do que vai ser a reação da SA contra sua sentença"20.

Nesse momento, o juiz estarrecido recebe o lanche da empregada que comenta que toda a vila está horrorizada com o acontecido. Todos sabem que a SA é uma instituição repleta de criminosos baderneiros, “... ainda bem que há justiça no país! Imaginem, agredir o pobre comerciante! (...) todas as pessoas de bem ficarão do seu lado, senhor juiz: é cem por cento." 21 .

Em seguida entra o conselheiro do Fórum, que vai trazer uma terceira opinião divergente tanto do inspetor quanto do promotor. Este diz que se o juiz absolver o judeu, a culpa deve cair em Wagner e a SA vai ficar satisfeita. Mas o sócio de Arndt pode querer pedir indenização das jóias na SA, e a instituição não vai gostar disso. O dono do prédio, no entanto, quer que Arndt seja inocentado por causa de umas promissórias que o ligam ao judeu. Com essa confusa discussão, entra o serventuário que diz que pessoas do alto escalão virão ao julgamento e não há cadeira para o juiz.

O juiz atônito diz que "(...) se a gente não sabe de que lado deve vir a decisão, então não há justiça!" Ao que o conselheiro retruca com uma afirmação angustiante: "não há conflitos no Terceiro Reich",22. Sabendo que não deve transparecer dúvida, mas cheio delas, o juiz se contorce mentalmente sobre como deve julgar o caso. Isto representa a esfera de intrusão do Estado totalitário em todos os aspectos do país. O judiciário é um mero fantoche das vontades daqueles que comandam o partido nazista.

No final, o serventuário em tom de piada diz que o Primeiro Promotor não aceitou ficar no banco das testemunhas e exige sentar-se à mesa do juiz, e que sendo assim resta ao juiz sentar-se no banco dos réus que foi o único lugar que sobrou.

A cena termina com um juiz atabalhoado se dirigindo para o julgamento sem nem mesmo saber de fato quem são os acusados.

Brecht usa toda essa situação patética para representar a falta de um sistema organizacional de justiça. Os tentáculos do partido nacional-socialista anulam o legislativo, falseiam o judiciário e se apossam do executivo de forma que a mera busca por justiça seja vista como crime capital.

Mas o Estado totalitário é expansivo a todos os domínios da sociedade, sejam eles públicos como no caso do judiciário ou privado como na família. Essa invasão do seio familiar por parte do Estado é trabalhada por Brecht com uma cena que tem grande destaque na obra: $O$ Espião.

\section{O espião}

"Ei-los: os senhores professores estão aprendendo a marchar. O nazistinha puxa-
lhes as orelhas e lhes ensina a posição de sentido. Cada aluno, um espião. Não
precisam saber nada do mundo ou do universo. Mas é interessante informar: o
que, de quem e quando. Aí vêm as criancinhas. Elas buscam o carrasco e o trazem

\footnotetext{
${ }^{20}$ Ibidem, p. 220.

${ }^{21}$ Ibidem, pp. 221-222.

${ }^{22}$ Ibidem, pp. 224-225.
} 
para casa. Delatam o próprio pai, chamam-no traidor. E ficam olhando, quando levam o velho de mãos e pés algemados.",23

No ano de 1935, em um dia de chuva após o almoço numa casa de família em Colônia. É este o cenário para a cena de $O$ Espião. Brecht utiliza aqui nesta cena praticamente um casal e seu filho para falar de um ponto importante do totalitarismo: o isolamento do indivíduo como elemento essencial do terror.

O início da história traz um diálogo entre o homem e a mulher sobre uma negativa dele em ter atendido ao telefonema de vizinhos. A mulher insiste que deveriam ter atendido porque eles devem saber que estão em casa: "você deveria ter ido ao telefone. Agora eles vão saber que não queremos vê-los" ${ }^{24}$. O grande conflito dessa cena está na situação incômoda do homem de não poder expressar seus pensamentos, e da mulher no medo que sente pelas palavras do marido. Os vizinhos que ligaram estão sofrendo processo de fiscalização e por esse motivo o marido acha melhor se afastarem.

A presença do Estado na esfera privada desse casal é transmitida por Brecht através de um crescente jogo psicológico que leva o leitor a uma angústia sufocante. "Dentro de minhas quatro paredes, posso dizer o que bem entender. Em minha própria casa não admito censura...." afirmação qualquer que tenha feito.

É logo em seguida a esse momento de tensão que o filho do casal, lendo um jornal questiona o pai sobre uma notícia contida nele. O pai pergunta o que ele está lendo e o menino diz ter sido orientado pelo Chefe-de-Grupo ${ }^{26}$ a procurar saber tudo o que está sendo dito nos jornais. O pai dá uma bronca no menino, dizendo-lhe "(...) o que você pode ou não ler, decido eu",27.

A mãe, para amenizar as coisas, dá um dinheiro para o menino e manda-o sair para comprar qualquer coisa. É a partir daqui que começam as elucubrações dos dois, em meio a uma discussão sobre o que se pode ou não falar, de onde teria ido o menino. A certa altura eles não lembram nem mesmo de ter dado o dinheiro ao menino.

A tensão cresce na medida em que começam a tentar lembrar do que estavam falando antes de o menino sair, ou o que ele teria ouvido. A mãe já muito nervosa diz: “(...) eles são abertamente estimulados a contar tudo o que ouvem em casa. Não deixa de ser estranho ele ter saído tão de mansinho"28.

O momento seguinte da cena gira em torno de o que possa ter sido dito que serviria de denúncia por parte do filho. “(...) o menino não ouve nada de positivo! Isso não é bom para uma personalidade em formação, só serve para prejudicar a juventude. E, como diz o Führer, a juventude alemã é o futuro alemão. (...) Estou me sentindo mal. Estou enjoada"29, diz a mãe.

Essa sensação de impotência e invasão da vida privada por parte do Estado é responsável pelo estado de terror que vive o casal. Hannah Arendt chama a atenção para o fato de que a destruição da esfera pública de debates é algo característico de governos

\footnotetext{
${ }^{23}$ Ibidem, p. 238.

${ }^{24}$ Ibidem, p. 239.

${ }^{25}$ Ibidem, p. 240.

${ }^{26}$ Em menção evidente de Brecht à Juventude Hitlerista.

${ }^{27}$ Ibidem, p. 240.

${ }^{28}$ Ibidem, p. 243.

${ }^{29}$ Ibidem, p. 245.
} 
autoritários, o que há de novo no regime totalitário é que a esfera privada - que tem na família a expressão por excelência - também tem seus laços destruídos. Essa anulação se dá através do isolamento do indivíduo. O terror desse indivíduo cresce na medida em que este sente não fazer parte de mais nada. Ele só pode existir enquanto massa, seus pensamentos não podem ser seus, são controlados, fiscalizados e denunciados até mesmo por um filho. A alternativa que sobra está no Estado, é só nele que o indivíduo vai encontrar sua função, onde ele sentirá de fato que é parte de alguma coisa.

A importância do teatro como aparelho privado é o que foi percebido desde muito cedo por Brecht como uma forma de propor reflexão - daí talvez uma resposta aos críticos que o acusam de não apontar soluções - e indagação a pessoas acostumadas a não refletir ou indagar. Não interessam soluções prontas, mas sim a necessidade e a busca do pensar por si mesmo. É claro que neste caso a obra propõe um rompimento com o isolamento imposto pelo totalitarismo, mas esta proposta não é direcionada apenas a quem vive na Alemanha nazista e sim a toda pessoa que possa vir a ser um agente político.

O insuportável da solidão que sentem os pais nessa cena é o fato de se estar perdido de si mesmo, isto é, não existe autonomia sobre pensamentos nem mesmo "entre quatro paredes" como diz o homem sob aflição. "Como ser professor? Formador da juventude? Eu tenho medo da juventude" ${ }^{30}$.

Já no fim da cena o telefone toca deixando ambos, marido e mulher, em pânico. Será que é o menino trazendo o carrasco pela mão? Será o Chefe-de-Grupo? O que vestir, o melhor lugar para pôr a foto de Hitler e o que dizer são os elementos que Brecht usa no fim desta história para aumentar a tensão. A porta bate e o casal se abraça em pânico. O garoto entra com um saco de bombons na mão. "Você foi só comprar chocolate?" ", é a pergunta da mãe, atônita. O menino diz que sim e atravessa a sala, enquanto os pais se olham e se questionam se ele estaria de fato falando a verdade.

$O$ Espião é uma cena mais curta que as outras duas que foram trabalhadas anteriormente, mas a sua importância está na discussão da fragilidade familiar perante o regime nazista. Qualquer pessoa que vá assistir a esta peça ou simplesmente lê-la sentirá nesta cena um desconforto muito grande. Porque é uma situação universal, que poderia ocorrer em qualquer família, e pior, a solidão sentida pelo indivíduo é algo que nos faz questionar quão importante é estar só, mas bem acompanhado.

Terror e Miséria do Terceiro Reich não é a obra mais citada de Brecht, nem é apresentada como uma grande obra dramática por aqueles que têm poder para dar este tipo de definição, mas é emblemática para se discutir o peso da contribuição de um intelectual que buscou com sua ferramenta defender valores universais para a humanidade.

Qual a relação desses intelectuais entre seu objeto, a política, e suas ferramentas sejam elas quais forem? Não se poderia fechar a discussão sem antes falar sobre quem seriam hoje os intelectuais, que como Brecht um dia o fez, buscam com suas ferramentas passar uma mensagem que está acima deles mesmos.

\section{Os intelectuais e suas ferramentas}

Bertolt Brecht foi um "intelectual orgânico" sob certos aspectos da definição gramsciana do termo. Mas não era estritamente ligado ao partido como Gramsci pregava

\footnotetext{
${ }^{30}$ Ibidem, p. 246.

${ }^{31}$ Ibidem, p. 250.
} 
que um intelectual deveria ser. Gramsci foi um dos fundadores do partido comunista italiano e, apesar de ser contemporâneo de Brecht, e viver situação similar no sentido de ser um intelectual vivendo sob regime fascista, Gramsci não via fora do partido a possibilidade de se alcançar mudanças significativas.

Brecht não investe na revolução por meio do partido. Para ele, as idéias marxistas estão deturpadas na Rússia stalinista, mesmo que ele pudesse enxergar esse regime como necessário para "conciliar os interesses do proletariado e dos camponeses" ${ }^{\text {"32 }}$, em conversa com Walter Benjamin.

Brecht vai fazer uso do teatro como sua ferramenta para a busca de um novo bloco histórico, muito por ver no teatro uma forma de construir diante das pessoas um modus operandi que propicie a discussão e a reflexão; mas há que se dizer também que o teatro e a poesia são o que Brecht sabe fazer.

Fernando Peixoto, em seu livro sobre vida e obra de Brecht, destaca um capítulo para falar de uma peça que Brecht escreveu servindo de parâmetro para a forma como o próprio Brecht enxergava a função do intelectual. Esta peça se chama A Vida de Galileu. É um tratado filosófico sobre todo o pensamento brechtiano desenvolvido através desse personagem que o poeta alemão escolhe como figura representativa do seu intelectual. Trabalha questões como culpa moral e crime social. É na constatação de que "(...) culpa moral é na realidade um erro político" ${ }^{33}$ que Brecht chama a atenção para algo que se diferencia do direito moral. Ambos têm ligação com a religião, mas a culpa traz um sentido negativo. Brecht fala da necessidade de se afastar a ciência da moral religiosa, quando os objetivos científicos não agridem os direitos morais. Brecht ressalta a traição de Galileu perante o povo, usando uma forte frase que diz mais ou menos o seguinte: "quem não conhece a verdade é um ignorante, mas quem a conhece e finge não conhecer é um criminoso" 34 .

Esse tipo de intelectual, com uma necessária autonomia dos aparelhos privados ou públicos de Estado, mas com forte necessidade em buscar algo maior que sua obra - a sobrevivência da humanidade - está presente no fim do século XX e início do século XXI.

O dramaturgo estadunidense Tony Kushner destaca o trabalho de Arthur Miller famoso dramaturgo, igualmente estadunidense, que escreveu entra outras obras, A Morte do Caixeiro Viajante e Gata em teto de Zinco Quente - como sendo um trabalho em busca da integridade pessoal ${ }^{35}$. O trabalho deste dramaturgo se orientou por preceitos humanistas acima de qualquer tipo de rótulo que possa ter um homem. Por isso, Kushner deixa claro em seu artigo que Arthur Miller jamais aceitou estar ligado a um partido ou a um grupo. Usou o teatro para falar de valores que devem ser buscados pelo homem, assim como Brecht, mas em método diferente. O contexto histórico de ambos era diferente. Kushner o denomina um escritor genuíno que brada para que “(...) reduzam o volume do entretenimento, o zurro da sensualidade pornográfica e lúrida, abandonem a prática de promulgar juízos como uma expressão de isolamento (...)"36. O contraponto entre Brecht $\mathrm{e}$ Arthur Miller se dá no fato de que ambos exercem suas reflexões fazendo uso do teatro como ferramenta. Ambos com focos distintos - Miller mais voltado ao indivíduo e Brecht

\footnotetext{
${ }^{32}$ PEIXOTO, Fernando. Op. cit., p 179.

${ }^{33}$ Ibidem, p 176.

${ }^{34}$ Ibidem, p. 178.

${ }^{35}$ KUSHNER, Tony. O Teatro da Liberdade. Folha de São Paulo, São Paulo, 24 Jul 2005. Caderno Mais, pp. 4-5.

${ }^{36}$ IDEM.
} 
atento ao poder transformador do grupo organizado - mas com o valor evidenciado em suas obras de suas funções enquanto agentes sociais.

Noam Chomsky, o renomado lingüista do Massachusetts Institute of Technology é outro exemplo desse tipo de intelectual orgânico que faz parte do cenário das relações internacionais. John Lechte faz menção à sua verve política lembrando que “(...) Chomsky também se tornou um declarado intelectual liberal de esquerda, que se opôs vigorosamente ao envolvimento da América na Guerra do Vietnã e escreveu uma dúzia de livros que lidam com questões políticas internacionais e domésticas atuais" ${ }^{\text {"37 }}$.

Chomsky trabalha em torno de questões de intervenção da política externa norteamericana, fazendo uso da filosofia e da lingüística enquanto ferramentas para proferir sua crítica política. A manipulação do público através da mídia e as estratégias utilizadas pelos governos estadunidenses para intervir em diversos lugares pelo mundo são temas freqüentes na sua obra. Chomsky faz uso ainda de uma gama muito grande de documentos que legitimam suas afirmações e de uma memória capaz de buscar fatos e datas em minúcias.

A apresentação de forma sucinta desses intelectuais e suas ferramentas tem o objetivo único de lembrar que a discussão acerca do trabalho de um homem como Bertolt Brecht não pode se restringir a um cenário histórico específico. Brecht já em sua obra $A$ Vida de Galileu se mostra contrário, no entanto, à superfluidade da função desse intelectual. Para ele, o herói não é uma dádiva, mas antes uma lástima. Quando Galileu fala com seu interlocutor Andréa, este afirma, "infeliz o país que não tem heróis!" ao que Galileu - com certeza transmitindo as palavras de Brecht - responde: "Não! Infeliz o país que tem necessidade de heróis" ${ }^{38}$.

\section{Referências Bibliográficas}

ARENDT, Hannah. Origens do totalitarismo. São Paulo: Companhia das Letras, 1989.

BRECHT, Bertolt. Coleção teatro. Direção de Fernando Peixoto. Rio de Janeiro: Paz e Terra, 1991, vol. 12.

ESSLIN, Martin. Brecht: dos males o menor, um estudo crítico do homem, suas obras e suas opiniões. Rio de Janeiro: Zahar Editores, 1979.

HOBSBAWM, Eric. Era dos extremos: o breve século XX: 1914-1991. São Paulo: Companhia das Letras, 2003.

KRISTOF, Nicholas D. A Sucker Bet. The New York Times, Nova Iorque, 17 Jul 2005. Opinion.

KUSHNER, Tony. O Teatro da Liberdade. Folha de São Paulo, São Paulo, 24 Jul 2005. Caderno Mais.

\footnotetext{
${ }^{37}$ LECHTE, John. Cinqüenta pensadores contemporâneos essenciais: do estruturalismo à pós-modernidade. Rio de janeiro: DIFEL, 2002, p. 65.

${ }^{38}$ PEIXOTO, Fernando. Op. cit, 1991, p. 177.
} 
LECHTE, John. Cinqüenta pensadores contemporâneos essenciais: do estruturalismo à pós-modernidade. Rio de Janeiro: DIFEL, 2002.

PEIXOTO, Fernando. Brecht, vida e obra. Rio de Janeiro: Paz e Terra, 1991.

SZKLARZ, Eduardo. Revista Superinteressante, São Paulo, ano19, n 7, Edição 215, Jul. 2005. 